\title{
Bat species composition associated with restinga lagoons from the Paulo César Vinha State Park, Espírito Santo, Brazil
}

\author{
Thiago Bernardi Vieira ${ }^{1,6}$; Liriann Chrisley Nascimento Da Silva ${ }^{1,7}$; Ludmilla Moura de Souza Aguiar ${ }^{2,8}$; \\ Monik Oprea ${ }^{3,9}$; Poliana Mendes ${ }^{4,10}$ \& Albert David Ditchfield ${ }^{5}, 11$
}

${ }^{1}$ Universidade Federal do Pará (UFPA), Faculdade de Ciências Biológicas (FCB), Laboratório de Ecologia. Altamira, PA, Brasil.

2 Universidade de Brasília (UNB), Instituto de Ciências Biológicas (ICB), Departamento de Zoologia, Laboratório de Ecologia e Conservação de Morcegos, Programa de Pós-Graduação em Ecologia. Brasília, DF, Brasil.

${ }^{3}$ Universidade Federal de Goiás (UFG), Instituto de Ciências Biológicas (ICB), Departamento de Ecologia (DECOL), Programa de Pós-Graduação em Ecologia e Evolução. Goiânia, GO, Brasil.

${ }^{4}$ Université Laval (ULAVAL), Faculté des Sciences de l'Agriculture et de l'Alimentation, Département de Phytologie. Québec, Québec, Canada.

${ }^{5}$ Universidade Federal do Espírito Santo (UFES), Departamento de Ciências Biológicas, Laboratório de Estudos em Quiropteros (LABEQ). Vitória, ES, Brasil.

${ }^{6}$ ORCID: http://orcid.org/0000-0003-1762-8294.E-mail: vieiratb@ufpa.com.br

7 ORCID: http://orcid.org/0000-0002-6219-7801. E-mail: lirianncns@gmail.com

${ }^{8}$ ORCID: http://orcid.org/0000-0002-9180-5052. E-mail: aguiar.ludmilla@gmail.com

${ }^{9}$ ORCID: http://orcid.org/0000-0001-5233-3198. E-mail:monik.bats@gmail.com

${ }^{10}$ ORCID: http://orcid.org/0000-0001-6061-3245.E-mail: polimendes@gmail.com

${ }^{11}$ ORCID: http://orcid.org/0000-0002-9597-1402.E-mail: trachops@gmail.com

\begin{abstract}
Restingas are coastal ecosystems associated with the Atlantic Forest. They are threatened by habitat degradation and forest fragmentation due to intense human occupation. Many restingas have coastal lagoons formed by bay sedimentation of bays, the presence of river estuaries, or emerging groundwater. The distance between lagoons and the ocean influences the biotic community in them. This study aimed to compare the diversity (composition, abundance and richness) of bat communities associated with three lagoons within the Paulo Cesar Vinha State Park, Espírito Santo state. Two lagoons ('Feia' and 'Vermelha' lagoons) are $2 \mathrm{~km}$ away from the ocean, while the third ('Carais' lagoon) is just a few meters distant from the ocean. Species composition did not differ among the lagoons. Abundance of Carollia perspicillata and Glossophaga soricina was higher in the 'Carais' lagoon. Abundance of Artibeus lituratus and Platyrrhinus lineatus was higher in the 'Vermelha' lagoon. Species with higher abundance in the 'Vermelha' are usually associated with urban and disturbed environments. 'Vermelha' lagoon is closer to human settlements and this could be a major driver of bat species abundance associated with this lagoon instead of distance from the ocean. These results may be used to guide conservations efforts in the restingas or habitats associated with restingas.
\end{abstract}

Keywords. Atlantic Forest; Chiroptera; Community; PEPCV; Riparian vegetation.

\section{INTRODUCTION}

Restingas are coastal ecosystems associated with the Atlantic Forest. They are threatened by habitat degradation and forest fragmentation due to intense human occupation (Esteves \& Lacerda, 2000). Many restingas have coastal brackish water lagoons formed by the sedimentation of bays, river estuaries or emerging groundwater (Esteves, 1998). They are characterized by a sand barrier separating them from the sea (Esteves, 1998). Surrounding the coastal lagoons and connecting the terrestrial and aquatic environments is the riparian zone, with great biodiversity and accumulation of organic matter (Gregory et al., 1991; Bendix, 1994; Naiman \& Decamps, 1997). Vegetation surrounding lagoons is influenced by the distance from the ocean, perimeter of the lagoon, and local conditions $\mathrm{pH}$, water temperature, soil moisture and type and organic matter concentration) (Caumette, 1992). Organic matter increases local productivity, allowing the formation of vegetation patches surrounded by xeromorphic vegetation, the latter characteristic of restinga (Enrich-Prast et al., 2004). These patches are important for food and shelter for many animal species, such as bats (see Kunz \& Kurta, 1988), as the other parts of the restinga are dominated 
by herbaceous and shrub vegetation (Martins, 1989; Menezes \& Araújo, 1999; Menezes et al., 2007).

Vegetation clutter is one of the most important vegetational trait affecting bat biodiversity (Macient et al., 2015). Bat species richness tend to be higher in riparian vegetation than in less cluttered vegetational types (Enrich-Prast et al., 2004). Bat species composition varies in the riparian vegetation depending on several factors such as vegetation structure and composition, connectivity with continuous vegetation, and degradation status (Luz et al., 2011). Neotropical bats have the most diversified feeding guilds among mammals (Kalko et al., 1996) and are important for pollination and seed dispersal (Fleming, 1988; Patterson et al., 2003). In restingas, there is a lack of even the most basic biological data, such as species composition and conservation status of their remnants (Rocha et al., 2005).

The composition of the bat communities and the structure of the assemblies are related mainly to the diversity of the vegetation and the structural variables of the environment (Hayes \& Gruver, 2000; Medellín et al., 2000; Estrada \& Coates-Estrada, 2001, 2002; Bobrowiec et al., 2014). Although natural and continuous forests are important for greater bat diversity and abundance (Meyer et al., 2016; Rocha et al., 2017a b; Soares et al., 2017), each species has a difference response to habitat degradation. While some are apparently unaffected, less tolerant species tend to shrink in numbers and more tolerant species to grow (Willig et al., 2007; Medellín et al., 2000; Meyer et al., 2016). Observed that in tropical forests physical obstruction gradients can influence and abundance and local composition of chiropteran species (Presley et al., 2008), since denser vegetation areas allow greater maneuverability in flight, they may reduce the foraging efficiency of some species (Arlettaz et al., 2001; Rainho et al., 2010; Fenton, 1990).

In southeastern Brazil, the Brazilian region with most data on bat distribution, knowledge on bat distribution is biased toward rainforests and restingas remain undersampled and under protected (Bergallo et al., 2003; Muylaert et al., 2017). It has been proposed that a minimum sampling effort of 1,000 captures is necessary to adequately sample bats in Atlantic Forest sites, such as restingas (Bergallo et al., 2003). Unfortunately not a single restinga site has achieved this minimum level of sampling effort, and therefore we do not have even the most basic biological information (species richness and composition) for restingas from Brazil.

This study aimed to assess the richness and composition of Chiroptera communities in the coastal lagoons from the Paulo Cesar Vinha State Park (PEPCV), State of Espírito Santo, Brazil. There are three lagoons in the PEPCV, a large one, Caraís lagoon, close to the ocean and two smaller ones, 'Feia' (meaning ugly in Portuguese) and Vermelha (meaning red), ca. $2 \mathrm{~km}$ from the ocean. Our initial assumption is that the 'Feia' and 'Vermelha' lagoons, that have similar distance from ocean, have a similar bat species composition compared to the 'Caraís' lagoon. This is expected because distance from ocean is a predictor for local conditions and vegetation clutter surrounding lagoons (Caumette, 1992).

\section{MATERIAL AND METHODS}

The Paulo Cesar Vinha State Park (PEPCV) was created by the State Decree No. 2993/90, being one of the last sandbanks in the coastline of the state of Espírito Santo (Rocha et al., 2005). The PEPCV is in the Guarapari municipality, southern coast of Espírito Santo $\left(20^{\circ} 32^{\prime} 02^{\prime \prime}\right.$ to $20^{\circ} 37^{\prime} 50^{\prime \prime} \mathrm{S}$ and $40^{\circ} 22^{\prime} 43^{\prime \prime}$ to $40^{\circ} 25^{\prime} 59^{\prime \prime} \mathrm{W}$ ) (Fig. 1) (IPEMA, 2005). According to the Köppen classification, the PEPCV has a tropical climate with wet summers and dry winters $(A w)$, average annual temperature is $23.3^{\circ} \mathrm{C}$, and the average annual rainfall is $1,307 \mathrm{~mm}$ (Fabris \& César, 1996). The soil in the PEPCV is sandy (Pereira, 1990; Fabris \& César, 1996), originated by marine deposits due to a change in the ocean level in the Holocene (Flexor et al., 1984).

It has $12 \mathrm{~km}$ of beaches, several typical formations of restinga and three lagoons: (i) Caraís, separated from the ocean by a narrow strip of sand, (ii) Feia and (iii) Vermelha are separated from the ocean by a sand strip of about $2 \mathrm{~km}$, they are not connected to the ocean and the vegetation is less dense than in the 'Carais' (IPEMA, 2005). Lake areas have high humidity and the vegetation constitutes of an herbaceous bog, Cyperaceae family (e.g., Sclearia latifolia, Cyperus articulatus, Eleocharis interstincta; Martins et al., 1999). Caraís has mangroves on one of its banks and is the only one among the three lagoons permanently connected to the sea (IPEMA, 2005; Oprea et al., 2009a) and the surroundings of this lagoon are occupied by a high density of Bombacacia sp. (Bombacaceae). During the wet season, the 'Caraís' lagoon occasionally present a connection to the ocean due to the higher water volume, favoring the development of a mangrove forest in one of its margins (IPEMA, 2005). Bat sampling was performed every two weeks, twice per month, for two consecutive days in different places, totaling 39 nights (Carais lagoon = 14; Feia lagoon = 13 and Lago Vermelha lagoon = 12), from September 2006 to August 2007, using 10 mist nets (six nets of $9.0 \times 2.5 \mathrm{~m}$ and four nets of $6.0 \times 2.5 \mathrm{~m}$ ) per night. Nets remained open for six hours after sunset and were checked every 30 minutes. They were placed around the three lagoons sampled in PEPCV, one lagoon per night of sampling. Due to its larger size, the 'Caraís' lagoon was divided into two (P1 and P2) sampling sites with five mist nets at each sampling point, this procedure was adopted to ensure the same sampling effort in each lagoon. Mist nets were always placed in different positions from previous nights, decreasing the probability of bat avoidance (Kalko et al., 1996). Captured animals were kept in cotton bags while their weight and forearm measurements were obtained. Bats were identified to the lowest taxonomic level, using the specific literature (e.g., Gardner, 2008) and two individuals from each species, one male and one female, were collected, conserved in $70 \%$ ethanol, and deposited at the mammal collection at Universidade Federal do Espírito Santo (UFES-MAM), Brazil. The sampling procedures were carried out with authorization № 57294-2 issued by the Biodiversity Information and Authorization System (SISBIO). The collections were carried out in 2004 , before the regulation of Law 11,794, of October 8, 2008, therefore, it does not 


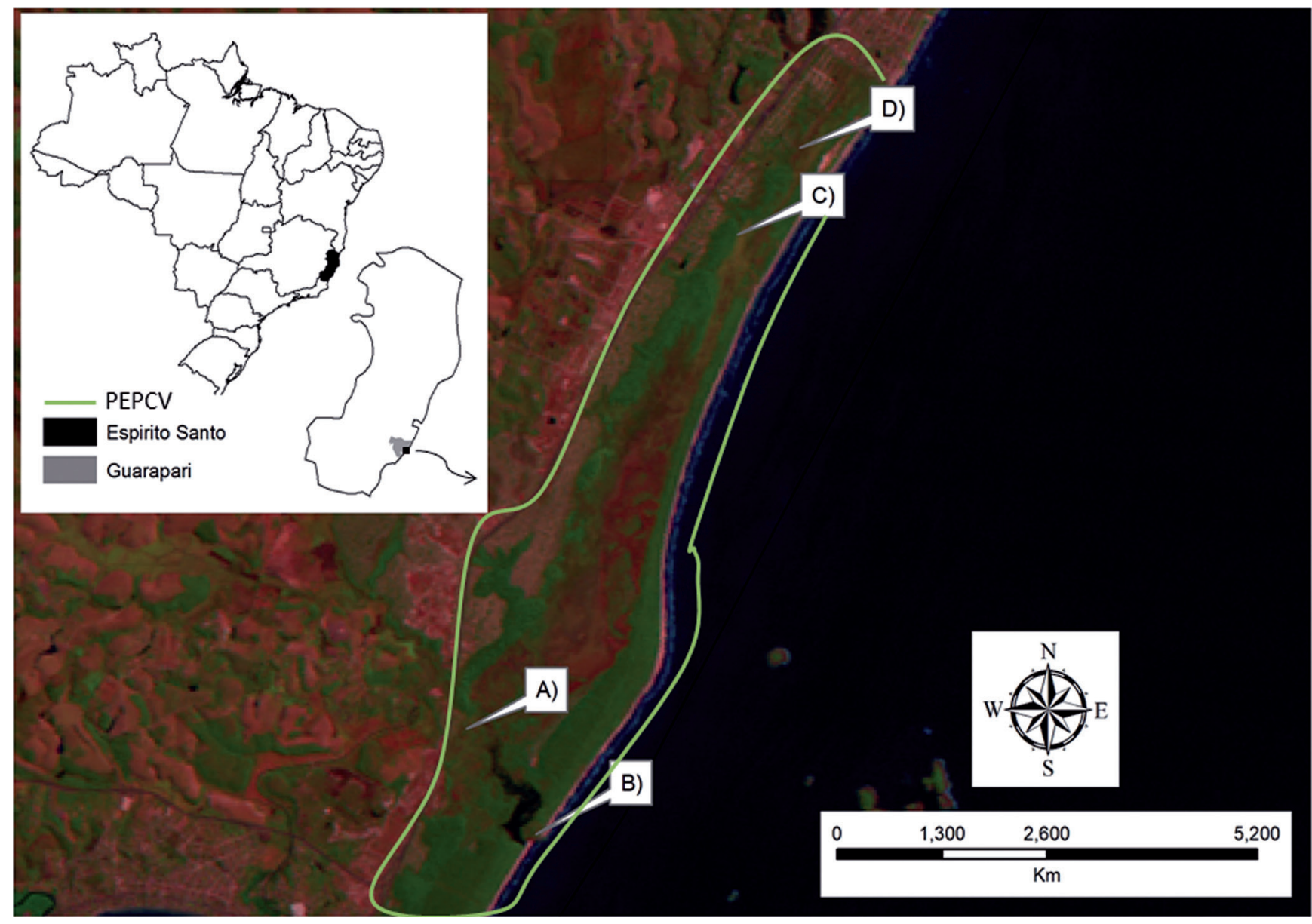

Figure 1. Location of the Paulo Cesar Vinha State Park - PEPCV within Brazil, State of Espírito Santo and Guarapari. Latter A and B are the Sampled point one (P1) and two (P2), letter $C$ and $D$ are Feia and Vermelha lagoon, respectively.

present the authorization document of the Commission for Experimentation and Use of Animals (CEUA).

A total of $80 \%$ of the captured individuals $(n=340)$ were tagged with numbered plastic collars (Esbérard \& Daemon, 1999) and released at the place of capture. The food guild was classified following Kalko et al., (1996). Sampling effort was calculated following Straube \& Bianconi (2002), and estimated richness was calculated using the first order Jackknife estimator (Heltshe \& Forrester, 1983) with 1,000 randomizations. Estimated and observed species richness was compared using the 95\% confidence intervals. Species richness in the three lagoons was compared using the intersection among confidence intervals of estimated species richness. For comparing the chiropteran composition among the three PEPCV lagoons, three procedures were adopted: (i) a principal component analysis (PCA), with the abundance matrix transformed by the Hellinger procedure (Legendre \& Gallagher, 2001), (ii) a non-parametric multivariate analysis of variance (PERMANOVA; Anderson, 2001), and (iii) a nonparametric multivariate variance analysis (Betadisper; Anderson, 2006) both analysis were performed using the Bray Curtis distance as a measurement of dissimilarity. A PCA was performed to visualize the distance among species in the community and the lagoons. However, it does not test the significance of the patterns and for this reason, we performed a PERMANOVA to look for a possible clustering pattern in the bat composition. Finally, to test the variance in bat composition in each lagoon, we performed a Betadisper analysis.

\section{RESULTS}

Bats of 12 species were captured in PEPCV (Table 1), totaling 395 captures and 22 recaptures, with a sampling effort of 49,200 h.m ${ }^{2}$ of mist nets. The majority of individuals belong to the Phyllostomidae family (98.8\%). Sampling completeness was not reached as the species estimator curve did not stabilize (Fig. 2). This is evident when we compare the observed richness to the final estimated richness, as their confidence intervals do not overlap (Fig. 2).

Artibeus lituratus (Olfers 1818) was the most common species in the three lagoons., Among the 232 individuals captured, 52 (22\%) were in Caraís lagoon, 85 (37\%) in Feia lagoon and 95 (41\%) in Vermelha lagoon. Another common species was Carollia persipicillata, second most abundant in the lagoons ( $23 \%$ of the total captures), inferior only to Plathyrrinus lineatus ( $n=12$ individuals) in the Feia lagoon. However, some species were unique, such as Anoura geoffroyi ( $\mathrm{n}=2$ individuals) in Caraís lagoon, Pygoderma bilabiatum $(\mathrm{n}=1)$ in Feia lagoon, Lasiurus blossevillii $(n=1)$, Phyllostomus discolor $(n=2)$ in the red 
Table 1. Bat composition sampled in the Paulo Cesar Vinha State Park, Espírito Santo State, Brazil, from September 2006 to August 2007.

\begin{tabular}{|c|c|c|c|c|c|}
\hline \multirow{2}{*}{$\begin{array}{l}\text { Family } \\
\text { Subfamily } \\
\text { Specie }\end{array}$} & \multirow{2}{*}{$\begin{array}{l}\text { Trophic } \\
\text { Guild }\end{array}$} & \multicolumn{4}{|c|}{ Lagoon } \\
\hline & & Carais & Feia & ermelh & Total \\
\hline \multicolumn{6}{|l|}{ Phyllostomidae Gray, 1825} \\
\hline \multicolumn{6}{|l|}{ Carolliinae Miller, 1924} \\
\hline Carollia perspicillata (Linnaeus, 1758) & Frugivorous & 29 & 8 & 59 & 96 \\
\hline \multicolumn{6}{|l|}{ Glossophaginae Bonaparte, 1845} \\
\hline Anoura geoffroyi Gray, 1838 & Nectarivorous & 2 & & & 2 \\
\hline Glossophaga soricina (Pallas, 1766) & Nectarivorous & 13 & 1 & & 14 \\
\hline \multicolumn{6}{|l|}{ Phyllostominae Gray, 1825} \\
\hline Phyllostomus discolor Wagner, 1843 & Omnivorous & & & 2 & 2 \\
\hline Phyllostomus hastatus (Pallas, 1767) & Omnivorous & & & 1 & 1 \\
\hline \multicolumn{6}{|l|}{ Stenodermatinae P. Gervais, 1856} \\
\hline Dermanura cinerea (Gervais, 1856) & Frugivorous & 3 & 5 & 10 & 18 \\
\hline Artibeus lituratus (0lfers, 1818) & Frugivorous & 52 & 85 & 95 & 232 \\
\hline Platyrrhinus lineatus (É. Geoffroy, 1810) & Frugivorous & 2 & 12 & 11 & 25 \\
\hline Pygoderma bilabiatum (Wagner, 1843) & Frugivorous & & 1 & & 1 \\
\hline Uroderma magnirostrum Davis, 1968 & Frugivorous & & 7 & 9 & 16 \\
\hline \multicolumn{6}{|l|}{ Vespertilionidae Gray, 1821} \\
\hline Lasiurus blossevillii (Lesson and Garnot, 1826) & Insectivorous & & & 1 & 1 \\
\hline Myotis nigricans (Schinz, 1821) & Insectivorous & 1 & 2 & 1 & 4 \\
\hline Abundance & & 102 & 121 & 189 & 412 \\
\hline Richness & & 7 & 8 & 9 & 12 \\
\hline
\end{tabular}

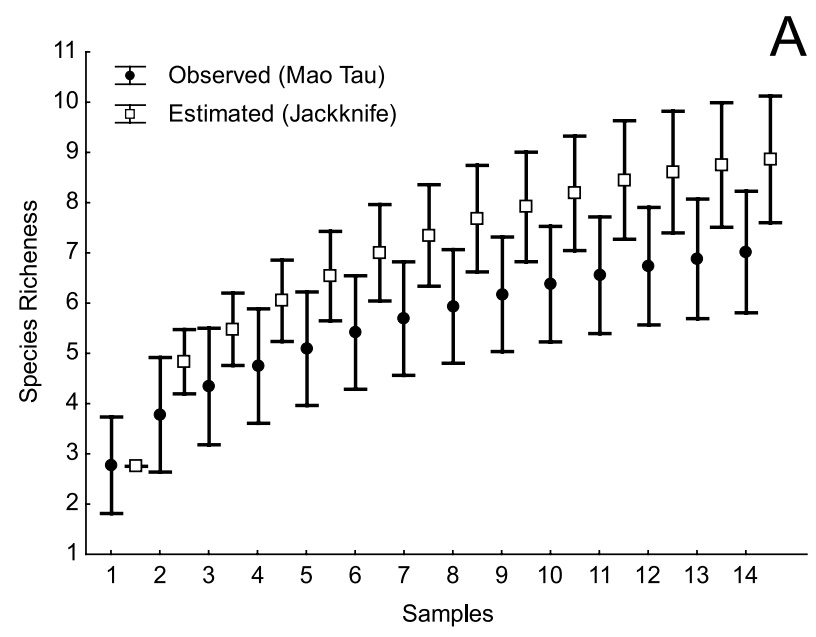

A

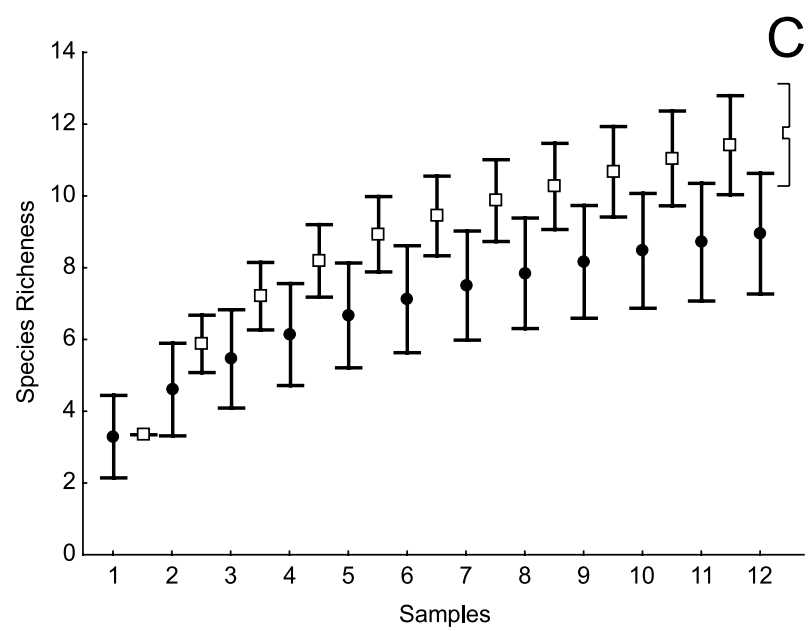

lagoon (Fig. 2). As for the trophic guild, we observed that frugivores are the most abundant in the three lagoons (Table 1). When individually analyzed, the species richness estimator for each of the three PEPCV lagoons also did not indicate a stabilization (Fig. 3). We sampled seven bat species at the Caraís lagoon, nine at the 'Feia', and ten at the Vermelha lagoon. Estimated species richness

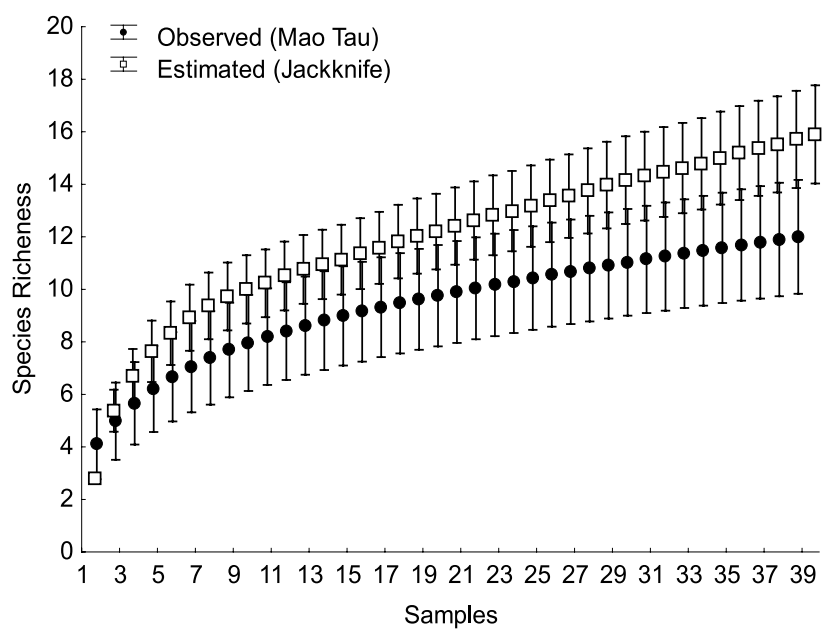

Figure 2. Observed and estimated bat species richness in the Paulo Cesar Vinha State Park - PEPCV, Espírito Santo, Brazil. Vertical bars represent 95\% confidence intervals.

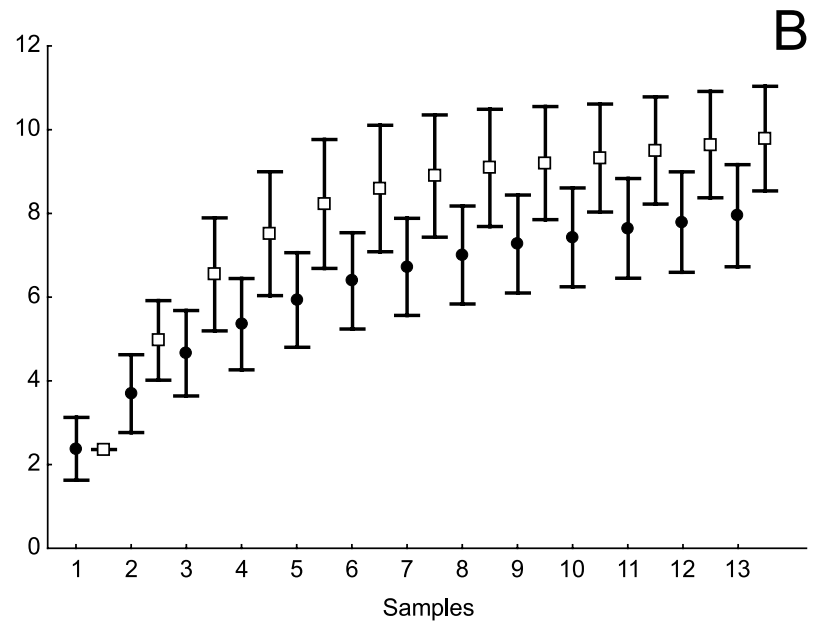

Figure 3. Observed and estimated bat species richness in the tree lagoons sampled in the Paulo Cesar Vinha State Park - PEPCV, Espírito Santo, Brazil. (A) 'Caraís' lagoon, (B) 'Feia' lagoon, (C) 'Vermelha' lagoon, and (D) Final observed and estimated species richness. Vertical bars represent $95 \%$ confidence intervals. 


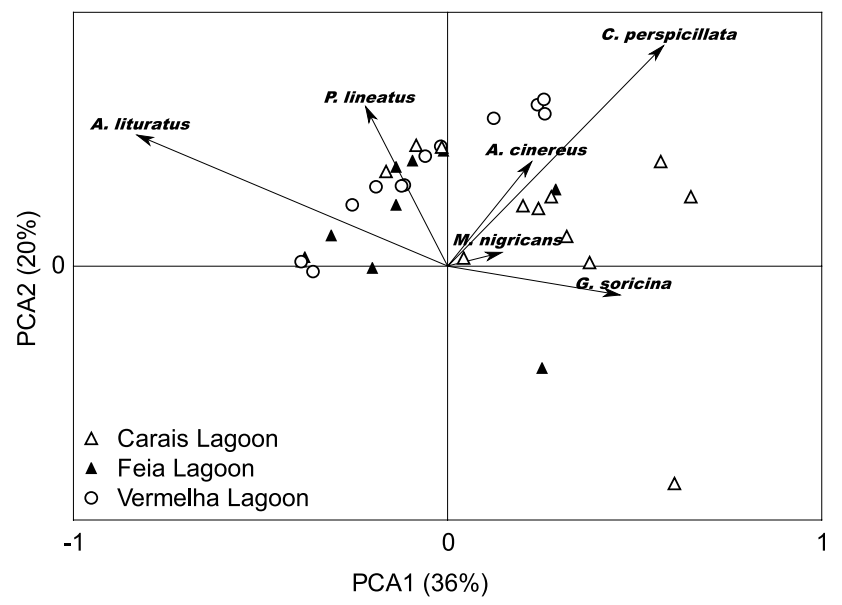

Figure 4. Principal Component Analyses of the bat composition in the Paulo CesarVinha State Park - PEPCV, Espírito Santo, Brazil. Ordination was performed by species abundance and the matrix was transformed by Hellinger procedure.

was nine, ten and twelve species, respectively. Observed species richness did not differ among the sampled lagoons. However, estimated richness was higher for the Vermelha lagoon (Fig. 3).

We did not observe a cluster pattern in the bat community among the three lagoons [(PERMANOVA $\left.\left(F_{(37,2)}=0.852 ; p=0.659\right)\right]$ and in the variance of the composition (Betadisper $\left.-\left(F_{(37,2)}=0.648, p=0.529\right)\right)(F i g .4)$. The abundance of Carollia perspicillata (Linnaeus 1758) and Glossophaga soricina (Pallas 1766) was larger at 'Caraís' lagoon. 'Vermelha' and 'Feia' lagoons had higher abundance of Artibeus lituratus and Platyrrhinus lineatus (É. Geoffroy 1810) (Fig. 4).

\section{DISCUSSION}

The higher abundance of Phyllostomidae species compared to other families can be explained by the use of mist nets as our sampling method. Mist nets captures are biased towards bats that use the lower stratum of vegetation, behavior observed in Phyllostomidae (Oprea et al., 2009a; Straube \& Bianconi, 2002; Calouro et al., 2010). Some of the frugivorous bats sampled in this study prefer plants usually found in degraded sites, such as Solanaceae, Piperaceae and Cecropiaceae, (MarinhoFilho, 1991; Zortéa \& Chiarello, 1994; Passos et al., 2003). Therefore, the high abundance of Phyllostomidae can be associated to different deforestation indeces, including forested areas with little fragmentation and large deforested areas with few and small patches of forest (Gorresen \& Willig, 2004). Frugivores were the most common bat guild in the study, which may also be a result from the use of mist nets to capture bats, as they capture predominantly frugivorous species (Kalko et al., 1996). Stenodermatinaea is the most diverse subfamily in the Neotropical region (Gardner, 2008). Among the species captured, there are species usually abundant and widely distributed in the Neotropics, including Phyllostomus hastatus, Glossophaga soricina, Carollia perspicillata, Artibeus lituratus, Platyrrhinus lineatus and Myotis nigri- cans (e.g., Peracchi \& Albuquerque, 1971, 1986; Pedro et al., 1995; Reis \& Müller, 1995; Bredt \& Uieda, 1996; Silva et al., 1996, Silva et al., 2005; Muylaert et al., 2017).

The species richness found was similar to other studies conducted in restingas, such as in the Parque Nacional da Restinga de Jurubatiba, Rio de Janeiro, with 14 species, (Mangolin, 2005), in the Restinga da Ilha de Guriri, Espirito Santo, with 9 species (Moreno et al., 2000), in Praia das Neves, Espírito Santo, with 17 species (Luz et al., 2011), and in PEPCV with 14 species (Oprea et al., 2009a). Desmodus rotundus, Chiroderma doriae and Chiroderma villosum were caught by Oprea et al., (2009a) in the same park we sampled (PEPCV), but were not captured in this study. On the other hand, Lasiurus blossevillii was not captured by Oprea et al., (2009a) but captured in this study. This species had only two records of occurrence in restinga, one collected by Ruschi (1951) and later registered during the data collection of this work, already mentioned by Vieira et al., (2009).

Lasiurus blossevillii is an aerial insectivore, which may justify its low sample representativeness in inventories using mist-nets (Shump-Jr. \& Shump, 1982; Genoways \& Baker, 1988). However, it has been recorded in every region of Brazil (Tavares \& Gregorin, 2008). Regardless, there is still difficulty in defining its geographic distribution, due to its low capture frequency (Rodrigues \& Ribas, 2011). All locations sampled in this study were in areas with water bodies. These environments allow for greater concentration and foraging of bats (Adams \& Simmons, 2002; Costa et al., 2012), which facilitates the capture of insectivores through the mist-nets (Esbérard et al., 2007; Lourenço et al., 2010; Costa et al., 2012), not always represented in other works (e.g., Gomes et al., 2016).

A total of 15 species have been recorded at PEPCV considering the Oprea et al. (2009a) study and the present one. This diversity makes the PEPCV one of the richest restingas in Brazil, along with the Reserva Biológica de Comboios and the Restinga de Praia das Neves, both in the Espírito Santo State. Our prediction that 'Feia' and 'Vermelha' lagoons would have a similar bat species composition compared to 'Caraís' lagoon due to the distance from the ocean was not corroborated. However, some differences were found related to the relative abundance of different species. The nectarivore $G$. soricina was more abundant in the Caraís lagoon and Anoura geoffroyi was recorded only in that locality. The high density of Bombacacia sp. (Bombacaceae) in this area would justify the presence of the two nectarivores (Fischer et al., 1992; Arias et al., 2009). Glossophaga soricina is frequent and abundant in open areas with 30 to $70 \%$ of tree cover (Ávila-Gómez et al., 2015), but low anthropogenic disturb. This species requires landscapes with a high percentage of the original forest cover (Ávila-Gómez et al., 2015; Klingbeil \& Willig, 2009, 2010).

We observed a higher abundance of Artibeus lituratus and Platyrrhinus lineatus in the 'Vermelha' Lagoon when compared to the other two lagoons. The 'Vermelha' lagoon is closer to human settlements when compared to the other lagoons, indicating a higher degree of disturbance in the vegetation surrounding this lagoon. Both 
species are common in urban environments (Oprea et al., 2007; Oprea et al., 2009b; Perini et al., 2003; Ferreira et al., 2010; Prone et al., 2012). Extraction ofsand and wood from restingas may affect bats, altering the composition and structure of vegetation, depleting food resources, and diversity of roosts (Soriano \& Ochoa, 2001). The magnitude of the disturbance may manifest itself as changes in species abundances and composition (Clarke et al., 2005a, b; Gorresen et al., 2005; Peters et al., 2006). However, despite presenting the highest degree of human disturbance, the Vermelha Lagoon had the highest number of captures, around 46\% ( $n=120)$, including 129 A. lituratus and 32 P. lineatus. The locality also had higher expected species richness.

The presence of a higher species richness in Vermelha lagoon may be result from the presence of pioneer plants in this area (IPEMA, 2005; Martins et al., 1999), like Cecropia (Urticaceae), Piper and Solanum that are commonly consumed by some species of frugivorous bats. In general, many frugivores and nectarivores exploit food resources provided by pioneer and successional plants (Fleming, 1988; Gorchov et al., 1993; Soriano \& Ochoa, 2001). The fruit production of primary forest is less seasonal than secondary species (Opler et al., 1980; Levey, 1988). For these reasons, moderate levels of deforestation increase spatial diversity and enhance abundances of early successional plants. Consequently, moderate or recently deforestation may increase food availability for frugivorous bat species that exploit disturbance-adapted plant species (Gorresen \& Willig, 2004).

Here, we observed that the three lagoons have similar bat composition. However, Caraís lagoon has species that are indicators of undisturbed or lowly disturbed sites (C. perspicillata and G. soricina). On the other hand, Vermelha lagoon has species that are correlated to disturbed areas ( $A$. lituratus), and the Feia lagoon may be intermediate in terms of disturbance, with intermediate abundance of $C$. perspicillata, G. soricina and A. lituratus. These results may be used to lead conservation efforts or guide new researches in the PEPCV or in the restingas and their associated.

\section{ACKNOWLEDGMENTS}

This study was financed in part by the Coordenação de Aperfeiçoamento de Pessoal de Nível Superior Brasil (CAPES) - Finance Code 001. We thank the State Environmental Institute of Espírito Santo for the collection authorization and the park staff for the accommodation.

\section{AUTHORS' CONTRIBUTIONS}

T.B.V.: Formal analysis, Writing - original draft. L.C.S.: Writing - review \& editing. L.M.S.A.: Writing-review \& editing. M.O.: Writing - review \& editing. P.M.: Writing review \& editing. A.D.D.: Supervision. All the authors actively participated in the discussion of the results, they reviewed and approved the final version of the paper.

\section{REFERENCES}

Adams, A.R.A. \& Simmons, J.A. 2002. Directionality of Drinking Passes by Bats at Water Hole there Cooperation? Acta Chiropterologica, 4(2): 195-199. DOI

Anderson, M.J. 2001. A new method for non-parametric multivariate analysis of variance. Austral Ecology, 26: 32-46. DOI

Anderson, M.J. 2006. Distance-based tests for homogeneity of multivariate dispersions. Biometrics, 62(1): 245-253. D01

Arias, E.; Cadenillas, R. \& Pacheco, V. 2009. Diet of nectarivorous bats from the National Park Cerros de Amotape, Tumbes. Revista Peruana de Biología, 16(2): 187-190.

Arlettaz, R.; Jones, G. \& Racey, P.A. 2001. Effect of acoustic clutter on prey detection by bats. Nature, 414(6865): 742-745. D0I

Ávila-Gómez, E.S.; Moreno, C.E.; García-Morales, R.; Zuria, I.; Sánchez-Rojas, G. \& Briones-Salas, M. 2015. Deforestation thresholds for phyllostomid bat populations in tropical landscapes in the Huasteca region, Mexico. Tropical Conservation Science, 8(3): 646-661. D01

Bendix, J. 1994. Riparian Landscapes. Geomorphology, 11(2): 172-73. D0I

Bergallo, H.G.; Esberard, C.E.L.; Mello, M.A.R.; Lins, V.; Mangolin, R.; Melo, G.G.S. \& Baptista, M. 2003. Bat Species Richness in Atlantic Forest: What Is the Minimum Sampling Effort? Biotropica, 35(2): 278-288. D0I

Bobrowiec, P.E.D.; Rosa, S.; Gazarini, J. \& Haugaasen, T. 2014. Phyllostomid bat assemblage structure in amazonian flooded and unflooded forests. Biotropica, 46(3): 312-321. D01

Bredt, A. \& Uieda, W. 1996. Bats from urban and rural environments of the Distrito Federal, mid-western Brazil. Chiroptera Neotropical, 2(2): 54-57. DOI

Calouro, A.M.; De Araújo Santos, F.G.; De Souza, S.F.; Lague, B.M.; Marciente, R.; De Lima Faustino, C.; Santos, G.J.L. \& Cunha, A.O. 2010. Riqueza e abundância de morcegos capturados na borda e no interior de um fragmento florestal do estado do Acre, Brasil. Biotemas, 4(23):109-117.D01

Caumette, P. 1992. Bacterial communities in coastal lagoons. An overview. Vie Milieu, 42(2): 111-123. Available: http://pascal-francis.inist.fr/vibad/ index.php?action=getRecordDetail\&idt=4413535.

Clarke, F.M.; Pio, D.V. \& Racey, P.A. 2005a. A comparison of logging systems and bat diversity in the Neotropics. Conservation Biology, 19(4): 1194-1204. DOI

Clarke, F.M.; Rostant, L.V. \& Racey, P.A. 2005b. Life after logging: post logging recovery of a neotropical bat community. Journal of Applied Ecology, 42(2): 409-420. DOI

Costa, L.M.; Luz, J.L. \& Esbérard, C.E.L. 2012. Riqueza de morcegos insetívo em lagoas no estado do Rio de Janeiro, Brasil. Papéis Avulsos Zoologia, São Paulo, 52(2): 7-19. D0I

Enrich-Prast, A.; Bozelli, R.L.; Esteves, F.A. \& Meirelles, F.P. 2004. Lagoas costeiras da Restinga de Jurubatiba: Descrição de suas variáveis limnológicas. In: Rocha, C.F.D.; Esteves, F.A. \& Scarano, F.R. (Eds.). Pesquisas de longa duração na Restinga de Jurubatiba - Ecologia, história natural e conservação RiMA. São Carlos, SP, RiMa Editon. p. 245-253.

Esbérard, C.E.L. \& Daemon C. 1999. Novo método para marcação de morcegos. Chiroptera Neotropical, 5(1-2): 116-117.

Esbérard, C.E.L.; Santos, B.S. \& Faria, D. 2007. New Thyroptera tricolor Spix records in the Atlantic Forest. Brazilian Journal of Biology, 67(2): 379-380. DOI

Esteves, F.A. 1998. Lagoas costeiras: origem, funcionamento e possibilidades de manejo. In: Esteves, F.A. (Ed.). Ecologia das lagoas costeiras do Parque Nacional da Restinga de Jurubatiba e do Município de Macaé (RJ). Rio de janeiro, NUPEM-UFRJ. p. 63-87.

Esteves, F.A. \& Lacerda, L.D. 2000. Restinga Brasileira: 15 anos de estudos. In: Ecologia de restingas e lagoas costeiras. UPEM/UFRJ, Macaé. 
Estrada, A. \& Coates-Estrada, R. 2001. Species composition and reproductive phenology of bats in a tropical landscape at Los Tuxtlas, Mexico. Journal of Tropical Ecology, 17(05): 627-646. DOI

Estrada, A. \& Coates-Estrada, R. 2002. Bats in continuous forest, forest fragments and in an agricultural mosaic habitat-island at Los Tuxtlas, Mexico. Biological Conservation, 103: 237-245. DOI

Fabris, L.C. \& César 0. 1996. Estudos florísticos em uma mata litorânea no sul do estado do Espírito Santo. Boletim do Museu de Biologia Mello Leitão (Nova série), 5: 15-46.

Fenton, M.B. 1990. The foraging behaviour and ecology of animal-eating bats. Canadian Journal of Zoology, 68(3): 411-422. D0I

Ferreira, C.M.M.; Fischer, E.; Pulchério-Leite, A. 2010. Fauna de morcegos em remanescentes urbanos de Cerrado em Campo Grande, Mato Grosso do Sul. Biota Neotropica, 10: 155-160. D0I

Fischer, E.A.; Jimenez, F.A. \& Sazima, M. 1992. Polinização por morcegos em duas espécies de Bombacaceae na Estação Ecológica de Juréia, São Paulo. Revista Brasileira de Botânica, 15(1): 67-72.

Fleming, T.H. 1988. The Short-Tailed Fruit Bat: A Study in Plant-Animal Interactions. University of Chicago Press, Chicago, IL, USA. p. 380

Flexor, J.M.; Martin, L.; Suguio, K. \& Dominguez, J.M.L. 1984. Gênese dos cordões arenosos da parte central da costa brasileira. In: Lacerda, L.D. (Ed.). Restingas: Origem, Estrutura e Processos. Niteroi, CEUFF. p. 327-342.

Gardner, A.L. 2008. Mammals of South America, Volume 1: Marsupials, Xenarthrans, Shrews, and Bats. New York, Chicago Press. 669p.

Genoways, H.H. \& Baker, R.J. 1988. Lasiurus blossevillii (Chiroptera: Vespertilionidae) in Texas. Texas Journal of Science, 40(1): 111-113. Available: https://digitalcommons.unl.edu/museummammalogy/265.

Gomes, L.A.C.; Maas, A.C.S.; Martins, M.A.; Pedrozo, A.R.; Araújo, R.M. \& Peracchi, A.L. 2016. Bats from an area of restinga in a conservation unit located in the state of Rio de Janeiro, southeastern Brazil. Neotropical Biology \& Conservation, 11(1): 31-37. D01

Gorchov, D.L.; Cornejo, F.; Ascorra, C. \& Jamarillo, M. 1993. The role of seed dispersal in the natural regeneration of rain forest after strip-cutting in the Peruvian Amazon. Vegetation, 107(108): 339-349. DOI

Gorresen, P.M. \& Willig, M.R. 2004. Landscape responses of Bats to habitat fragmentation in Atlantic Forest of Paraguay. Journal of Mammalogy, 85(4): 688-697. DOI

Gorresen, P.M.; Willig, M.R. \& Strauss, R.E. 2005. Multivariate analysis of scale-dependent associations between bats and landscape structure. Ecological Applications, 15: 2126-2136. D0I

Gregory, S.V.; Frederick, J.S.; Arthur, M.W. \& Cummins, K.W. 1991. An ecosystem perspective of riparian zones. BioScience, 41(8): 540-51. D0I

Hayes, J.P. \& Gruver, J.C. 2000. Vertical stratification ol bat activity in an old-growth forest in western vertical stratification ol bat activity in an old-growth forest in western Washington. Northwest Science, 74(2): 102-108. Available: $\mathrm{http} / / / \mathrm{hdl}$.handle.net/2376/1060.

Heltshe, J. \& Forrester, N.E. 1983. Estimating species richness using the jackknife procedure. Biometrics, 39: 1-11.

Instituto de Permacultura e Ecovilas da Mata Atlântica (IPEMA). 2005. Conservação da Mata Atlântica no Estaddo do Espiríto Santo: Cobertura florestal e unidades de conservação (Programa Centro para Conservação da Biodiversidade - Conservação Internacional do Brasil). Vitória, Conservação Internacional do Brasil \& IPEMA. p. 112.

Kalko, E.K.V.; Handley, C. \& Handley, D. 1996. Organization, diversity, and long term dynamics of a Neotropical bat community. In: Cody, M. \& Smallwood, J. (Eds.). Long Term studies in vertebrates communities. Los Angeles, Academic Press. p. 503-553.

Klingbeil, B.T. \& Willig, M.R. 2009. Guild-specific responses of bats to landscape composition and configuration in fragmented Amazonian rainforest. Journal of Applied Ecology, 46: 203-213. D0I
Klingbeil, B.T. \& Willig, M.R. 2010. Seasonal differences in population-, ensemble- and community-level responses of bats to landscape structure in Amazonia. Oikos, 119: 1654-1664. DOl

Kunz, T.H. \& Kurta, A. 1988. Capture methods and holding devices. In: Kunz, T.H. (Ed.). Ecological and behavioral methods for the study of bats. Washington, D.C.; Smithsonian Institution Press. p. 1-29.

Legendre, P. \& Gallagher, E.D. 2001. Ecologically meaningful transformations for ordination of species data. Oecologia, 129:271-280. DOI

Levey, D.J. 1988. Spatial and Temporal Variation in Costa Rican Fruit and FruitEating Bird Abundance. Ecological Monographs, 58(4): 251-269. D0I

Lourenço, E.C.; Costa, L.M.; Silva, R.M. \& Esbérard, C.E.L. 2010. Bat diversity of Ilha da Marambaia, Southern Rio de Janeiro State, Brazil (Chiroptera, Mammalia). Brazilian Journal Biology, 70(3): 511-520. D01

Luz, J.L.; Mangolin, R.; Esbérard, C.E.L. \& Bergallo H.G. 2011. Morcegos (Chiroptera) capturados em lagoas do Parque Nacional da Restinga de Jurubatiba, Rio de Janeiro, Brasil. Biota Neotropica, 11(4): 161-168. D0I

Macient, R.; Bobrowiec, P.E.D. \& Magnusson, W.E. 2015. Ground-Vegetation Clutter Affects Phyllostomid Bat Assemblage Structure in Lowland Amazonian Forest. PlosOne, 10(6): 1-16. DOI

Mangolin, R. 2005. Quiropteros (Mammalia: quiroptera) do Parque Nacional da Restinga de Jurubatiba. Rio de Janeiro, Brasil. Masters dissertation, Universidade Estadual do Rio de Janeiro.

Marinho-Filho, J.S. 1991. The coexistence of two frugivorous bat species and the phenology of their food plants in Brazil. Journal of Tropical Ecology, Cambridge, 7:59-67. D01

Martins, F.R. 1989. Fitossociologia de florestas no Brasil: um histórico bibliográfico. Pesquisas - Série Botânica, São Leopoldo, 40: 103-164.

Martins, M.L.L.; Carvalho-Okano, R.M. \& Luceño, M. 1999. Cyperaceae do Parque Estadual Paulo César Vinha, Guarapari, Espírito Santo, Brasil. Acta botânica Brasilica, 13(2): 187-222.

Medellín, R.A.; Equihua, M. \& Amin, M.A. 2000. Bat Diversity and Abundance as Indicators of Disturbance in Neotropical Rainforests. Conservation Biology, 14(6): 1666-1675. DOI

Menezes, L.F.T. \& Araújo, D.S.D. 1999. Estrutura de duas formações vegetais no cordão externo da Restinga da Marambaia, RJ. Acta Botânica Brasílica, 13(2): 223-235. DOI

Menezes, L.F.T.; Souza, M. \& Castro, D.N. 2007. Estrutura da formação arbustiva aberta não inundável na Restinga de Marambaia (RJ). Revista Brasileira de Biociência, 5: 75-77.

Meyer, C.F.J.; Struebig, M. \& Willig, M.R. 2016. Responses of Tropical Bats to Habitat Fragmentation, Logging, and Deforestation. In: Voigt, C.C. \& Kingston, T. (Eds.). Bats in the anthropocene: conservation of bats in a changing. Lisboa, Springer. p. 63-102.

Moreno, M.R.; Marinato, C.S.; Silve, V.J.M.; Pariz, S. \& Nascimento, M.T. 2000. Morcegos da restinga da ilha de Guriri, São Mateus, Espírito Santo e a dispersão de sementes de Solanaceae e Cactaceae. In: Simpósio de Ecossistemas Brasileiros, $5^{\circ}$. Anais. Vitória, ACIESP. p. 31-38.

Muylaert, R.D.L.; Stevens, R.D.; Esbérard, C.E.; Mello, M.A.; Garbino, G.S.; Varzinczak, L.H.; Faria, F.; Weber, M.D.M; Rogeri, P.K.R.; Regolin, A.L.; Oliveira, H.F.D.; Costa, L.D.M.; Barros, M.A.S; Sabino-Santos-Jr., G.; Morais, M.A.C.;Kavagutti, V.S.;Passos, F.C.;Marjakangas, E.L.; Maia, F.G.M.; Ribeiro \& Galetti, M.C. 2017. Atlantic bats: a data set of bat communities from the Atlantic forests of South America. Ecology, 98(12): 3227-3227. DOI

Naiman, R.J. \& Decamps, H. 1997. The Ecology of Interfaces: Riparian Zones. Annual Review of Ecology and Systematics, 28: 621-58. DOI

Opler, P.A.; Frankie, G.W. \& Baker, H.G. 1980. Comparative Phenological Studies of Treelet and Shrub Species in Tropical Wet and Dry Forests in the Lowlands of Costa Rica. The Journal of Ecology, 68(1): 167. D0I

Oprea, M.; Brito, D.; Vieira, T.B.; Mendes, P.; Lopes, S.R.; Fonseca, R.M.; Coutinho, R.Z. \& Ditchfield, A.D. 2007. A note on the diet and foraging 
behavior of Artibeus lituratus (Chiroptera, Phyllostomidae) in an urban park in southeastern Brazil. Biota Neotropica, 7(2): 297-300. D0I

Oprea, M.; Esberard, C.E.L.; Vieira, T.B.; Mendes, P.; Pimenta, V.T.; Brito, D. \& Ditchfield, A.D. 2009a. Bat community species richness and composition in a restinga protected area in southeastern Brazil. Brazilian Journal of Biology, 69: 1073-1079. DOI

Oprea, M.; Mendes, P.; Vieira, T.B. \& Ditchfield, A.D. 2009b. Do wooded streets provide connectivity for bats in an urban landscape? Biodiversity and Conservation, 18: 2361-2371. DOI

Passos, F.C.; Silva, W.R.; Pedro, W.A. \& Bonin, M.R. 2003. Frugivoria em morcegos (Mammalia, Chiroptera) no Parque Estadual Intervales, sudeste do Brasil. Revista Brasileira de Zoologia, 20(3): 511-517. D01

Patterson, B.D.; Willig, M.R. \& Stevens, R.D. 2003. Trophic strategies, niche partitioning, and patterns of ecological organization. In: Kunz, T.H. \& Fenton, M.B. Bat Ecology. University of Chicago Press. p. 536-557.

Pedro, W.; Geraldes, M.P.; Lopez, G.G. \& Alho, C.J.R. 1995. Fragmentação de hábitat e a estrutura de uma taxocenose de morcegos em São Paulo (Brasil). Chiroptera Neotropical, 1(1): 4-6. Available: http://www. chiroptera.unb.br/index.php/cn/article/view/4/17.

Peracchi, A.L. \& Albuquerque, S.T. 1971. Lista provisória dos Chiropteros dos Estados do Rio de Janeiro e Guanabara (Chiroptera; Mammalia). Revista Brasileira de Biologia, 31: 405-413. Available: https://www.icmbio.gov. br/parnaserradosorgaos/images/stories/Moratelli Peracchi_2007.pdf.

Peracchi, A.L. \& Albuquerque, S.T. 1986. Quirópteros do Estado do Rio de Janeiro, Brasil (Mammalia, Chiroptera). Publicações Avulsas do Museu Nacional, 66: 63-69.

Pereira, 0.J. 1990. Caracterização fito fisionômica da restinga de Setiba Guarapari, ES. In: Watanabe, S. (Ed.). Simpósio de Ecossistemas da Costa Sul e Sudeste Brasileira, 2. Anais. São Paulo, ACIESP. v. 3, p. 207-219.

Perini, F.A.; Tavares, V.C. \& Nascimento, C. 2003. Bats from the city of Belo Horizonte, Minas Gerais, southeastern Brazil. Chiroptera Neotropical, 9(1-2): 169-173. Available: https://pesquisa.bvsalud.org/portal/resource/pt/vti-464726.

Peters, S.L.; Malcolm, J.R. \& Zimmerman, B.L. 2006. Effects of selective logging on bat communities in the south eastern Amazon. Conservation Biology, 20: 1410-1420. D0I

Presley, S.J.; Willig, M.R.; Wunderle, J.M. \& Saldanha, L.N. 2008. Effects of reduced-impact logging and forest physiognomy on bat populations of lowland Amazonian forest. Journal of Applied Ecology, 45: 14-25. Available: https://www.fs.usda.gov/treesearch/pubs/29983.

Prone, B.; Zanon, C.M.V. \& Benedito, E. 2012. Bats (Chiroptera, Phyllostomidae) in the urbanized area in South of Brazil. Acta Scientiarum. Biological Sciences, 34(2): 155-162. DOI

Rainho, A.; Augusto, A.M. \& Palmeirim, J.M. 2010. Influence of vegetation clutter on the capacity of ground foraging bats to capture prey. Journal of Applied ecology, 47(4): 850-858. DOI

Reis, N.R. \& Muller, M.F. 1995. Bat diversity of forests and open areas in a subtropical region of south Brazil. Ecologia Austral, 5: 31-36.

Rocha, C.F.D.; Van Sluys, M.; Bergallo, H.G. \& Alves, M.A.S. 2005. Endemic and threatened tetrapods in the restingas of the biodiversity corridors of Serra do Mar and of the central da Mata Atlântica in Eastern Brazil. Brazilian Journal of Biology, 65(1): 159-168. D0I

Rocha, R.; Ferreira, D.F.; López-Baucells, A.; Farneda, F.Z.; Carreiras, J.M.B.; Palmeirim, J.M. \& Meyer, C.F.J. 2017a. Does sex matter? Gender-specific responses to forest fragmentation in Neotropical bats. Biotropica, 49(6): 881-890. DOI

Rocha, R.; Lópes-Baucells, A.; Farneda, F.Z.; Groenenberg, M.; Bobrowiec, P.E.D.; Palmeirim, J.M.C. \& Meyer, C.F.J. 2017b. Consequences of a largescale fragmentation experiment for Neotropical bats: disentangling the relative importance of local and landscape-scale effects. Landscape Ecology, 32: 31-45. DOI

Rodrigues, L.R.R. \& Ribas, T.F.A. 2011. Novo registro de Lasiurus blossevillii Lesson \& Garnot, 1826 (Chiroptera, Vespertilionidae) na região de Santarém, oeste do Pará. Revista Brasileira de Zoociências, 13(1, 2, 3): 11-17. DOI

Ruschi,A. 1951. Morcegos do estado do Espirito Santo. FamíliaVespertilionidae, chave analítica para os gêneros e espécies representadas no E. Santo. Descrição de Myotis nigricans nigricans e Myotis espiritosantensis n. sp. e algumas observações a seu respeito. Boletim do Museu de Biologia Profesor Mello Leitão, 4: 1-11.

Shump-Jr., K.A. \& Shump, A.U. 1982. Lasiurus borealis. Mammalian Species, 183: 1-6. DOI

Silva, M.M.S.; Harmani, E.F.B.; Gonçalves, E.F.B. \& Uieda, W. 1996. Bats from the metropolitan region of São Paulo, Southern Brazil. Chiroptera Neotropical, 2(1): 39-41.

Silva, R.; Perini, F.A. \& Oliveira, W.R. 2005. Morcegos da cidade de Itabira, Minas Gerais, sudeste do Brasil. Chiroptera Neotropical, 11: 216-219.

Soares, F.A.M.; Ribeiro, C.E.B.P.; Daher, M.R.D.M.; Guerra, D.D.Q. \& Ferrari, S. 2017. Bats (Mammalia: Chiroptera) from a remnant of Atlantic Forest in Pernambuco, northeastern Brazil. Revista Brasileira de Zoociências, 18(1): 53-66. DOI

Soriano, P.J. \& Ochoa, J. 2001. The consequences of timber exploitation for bat communities in tropical America. In: Fimbel, R.A.; Grajal, A. \& Robinson, J.G. (Eds.). The cutting edge: conserving wildlife in logged tropical forest Columbia. New York, University Press. p. 153-166.

Straube, F.C. \& Bianconi, G.V. 2002. Sobre a grandeza e a unidade utilizada para estimar esforço de captura com utilização de redes-de-neblina. Chiroptera Neotropical, 8(1-2): 150-152. Available: https://www. semanticscholar.org/paper/Sobre-a-grandeza-e-a-unidade-utilizadapara-estimar-Straube-Bianconi/7b4901065b386431acc2d21b66d6822 b2eeafb2e.

Tavares, V.C. \& Gregorim, R. 2008. A diversidade de morcegos no Brasil: Lista atualizada com comentários sobre distribuição e taxonomia. In: Pacheco, S.M.; Marques, R.V. \& Esbérard, C.E. (Eds.). Morcegos no Brasil: biologia, ecologia e conservação. Porto Alegre, Armazém Digital. p. 25-60.

Vieira, T.B.; Mendes, P.; Oprea, M. \& Ditchfield, A.D. 2009. New record of Lasiurus blossevillii (Chiroptera: Vespertilionidae) for the restinga ecosystem, and second occurrence for the state of Espírito Santo, southeastern Brazil. Mammalia, 73(2): 155-157.

Willig, M.R.; Presley, S.J.; Bloch, C.P.; Hice, C.L.; Yanoviak, S.P.; Díaz, M.M.; Chauca, L.A.; Pacheco, V. \& Weaver, S.C. 2007. Phyllostomid Bats of Lowland Amazonia: Effects of Habitat Alteration on Abundance. Biotropica, 39(6): 737-746. D01

Zortéa, M. \& Chiarello, A.G. 1994. Observations on the big fruit-eating bat, Artibeus lituratus, in an Urban Reserve of South-east Brazil. Mammalia, Paris, 58(4): 665-670. Available: http://pascal-francis.inist.fr/vibad/ index.php?action=getRecordDetail\&idt=3403367. 


\section{APPENDIX}

\begin{tabular}{|c|c|c|c|c|}
\hline Family & Subfamily & Specie & Code & Location \\
\hline Phyllostomidae & Carolliinae & Carollia perspicillata & TV 28 & Laboratório de Estudos de Quirópteros (LABEQ) from the Federal University of Espírito Santo (UFES) \\
\hline Phyllostomidae & Carolliinae & Carollia perspicillata & TV 34 & Laboratório de Estudos de Quirópteros (LABEQ) from the Federal University of Espírito Santo (UFES) \\
\hline Phyllostomidae & Carolliinae & Carollia perspicillata & TV 71 & Laboratório de Estudos de Quirópteros (LABEQ) from the Federal University of Espírito Santo (UFES) \\
\hline Phyllostomidae & Glossophaginae & Anoura geofroyii & TV 78 & Laboratório de Estudos de Quirópteros (LABEQ) from the Federal University of Espírito Santo (UFES) \\
\hline Phyllostomidae & Glossophaginae & Glossophaga soricina & TV 26 & Laboratório de Estudos de Quirópteros (LABEQ) from the Federal University of Espírito Santo (UFES) \\
\hline Phyllostomidae & Glossophaginae & Glossophaga soricina & TV 35 & Laboratório de Estudos de Quirópteros (LABEQ) from the Federal University of Espírito Santo (UFES) \\
\hline Phyllostomidae & Glossophaginae & Glossophaga soricina & TV 38 & Laboratório de Estudos de Quirópteros (LABEQ) from the Federal University of Espírito Santo (UFES) \\
\hline Phyllostomidae & Glossophaginae & Glossophaga soricina & TV 56 & Laboratório de Estudos de Quirópteros (LABEQ) from the Federal University of Espírito Santo (UFES) \\
\hline Phyllostomidae & Phyllostominae & Phyllostomus discolor & TV 64 & Laboratório de Estudos de Quirópteros (LABEQ) from the Federal University of Espírito Santo (UFES) \\
\hline Phyllostomidae & Phyllostominae & Phyllostomus hastatus & TV 31 & Laboratório de Estudos de Quirópteros (LABEQ) from the Federal University of Espírito Santo (UFES) \\
\hline Phyllostomidae & Stenodermatinae & Artibeus lituratus & TV 25 & Laboratório de Estudos de Quirópteros (LABEQ) from the Federal University of Espírito Santo (UFES) \\
\hline Phyllostomidae & Stenodermatinae & Artibeus lituratus & TV 27 & Laboratório de Estudos de Quirópteros (LABEQ) from the Federal University of Espírito Santo (UFES) \\
\hline Phyllostomidae & Stenodermatinae & Artibeus lituratus & TV 32 & Laboratório de Estudos de Quirópteros (LABEQ) from the Federal University of Espírito Santo (UFES) \\
\hline Phyllostomidae & Stenodermatinae & Artibeus lituratus & TV 33 & Laboratório de Estudos de Quirópteros (LABEQ) from the Federal University of Espírito Santo (UFES) \\
\hline Phyllostomidae & Stenodermatinae & Artibeus lituratus & TV 37 & Laboratório de Estudos de Quirópteros (LABEQ) from the Federal University of Espírito Santo (UFES) \\
\hline Phyllostomidae & Stenodermatinae & Artibeus lituratus & TV 39 & Laboratório de Estudos de Quirópteros (LABEQ) from the Federal University of Espírito Santo (UFES) \\
\hline Phyllostomidae & Stenodermatinae & Artibeus lituratus & TV 40 & Laboratório de Estudos de Quirópteros (LABEQ) from the Federal University of Espírito Santo (UFES) \\
\hline Phyllostomidae & Stenodermatinae & Artibeus lituratus & TV 41 & Laboratório de Estudos de Quirópteros (LABEQ) from the Federal University of Espírito Santo (UFES) \\
\hline Phyllostomidae & Stenodermatinae & Artibeus lituratus & TV 49 & Laboratório de Estudos de Quirópteros (LABEQ) from the Federal University of Espírito Santo (UFES) \\
\hline Phyllostomidae & Stenodermatinae & Artibeus lituratus & TV 50 & Laboratório de Estudos de Quirópteros (LABEQ) from the Federal University of Espírito Santo (UFES) \\
\hline Phyllostomidae & Stenodermatinae & Artibeus lituratus & TV 51 & Laboratório de Estudos de Quirópteros (LABEQ) from the Federal University of Espírito Santo (UFES) \\
\hline Phyllostomidae & Stenodermatinae & Artibeus lituratus & TV 54 & Laboratório de Estudos de Quirópteros (LABEQ) from the Federal University of Espírito Santo (UFES) \\
\hline Phyllostomidae & Stenodermatinae & Artibeus lituratus & TV 62 & Laboratório de Estudos de Quirópteros (LABEQ) from the Federal University of Espírito Santo (UFES) \\
\hline Phyllostomidae & Stenodermatinae & Artibeus lituratus & TV 63 & Laboratório de Estudos de Quirópteros (LABEQ) from the Federal University of Espírito Santo (UFES) \\
\hline Phyllostomidae & Stenodermatinae & Dermanura cinerea & TV 29 & Laboratório de Estudos de Quirópteros (LABEQ) from the Federal University of Espírito Santo (UFES) \\
\hline Phyllostomidae & Stenodermatinae & Dermanura cinerea & TV 36 & Laboratório de Estudos de Quirópteros (LABEQ) from the Federal University of Espírito Santo (UFES) \\
\hline Phyllostomidae & Stenodermatinae & Dermanura cinerea & TV 48 & Laboratório de Estudos de Quirópteros (LABEQ) from the Federal University of Espírito Santo (UFES) \\
\hline Phyllostomidae & Stenodermatinae & Dermanura cinerea & TV 55 & Laboratório de Estudos de Quirópteros (LABEQ) from the Federal University of Espírito Santo (UFES) \\
\hline Phyllostomidae & Stenodermatinae & Pigoderma bilabiatum & TV 61 & Laboratório de Estudos de Quirópteros (LABEQ) from the Federal University of Espírito Santo (UFES) \\
\hline Phyllostomidae & Stenodermatinae & Uroderma magnirostrum & TV 70 & Laboratório de Estudos de Quirópteros (LABEQ) from the Federal University of Espírito Santo (UFES) \\
\hline Phyllostomidae & Stenodermatinae & Uroderma magnirostrum & TV 72 & Laboratório de Estudos de Quirópteros (LABEQ) from the Federal University of Espírito Santo (UFES) \\
\hline Vespertilionidae & & Lasiurus blossevillii & TV 53 & Laboratório de Estudos de Quirópteros (LABEQ) from the Federal University of Espírito Santo (UFES) \\
\hline Vespertilionidae & & Myotis nigricans & TV 42 & Laboratório de Estudos de Quirópteros (LABEQ) from the Federal University of Espírito Santo (UFES) \\
\hline Vespertilionidae & & Myotis nigricans & TV 47 & Laboratório de Estudos de Quirópteros (LABEQ) from the Federal University of Espírito Santo (UFES) \\
\hline
\end{tabular}

